\title{
EAl Endorsed Transactions

\section{The Key Managerial Competencies Tendencies Application in the Business Environment in Slovakia within the Context of Industry 4.0}

\section{Z. Stacho ${ }^{1, *}$, K. Stachová ${ }^{1}$, D. Cagáňová ${ }^{2}$ and J. Blštákováa ${ }^{3}$}

${ }^{1}$ Institute of Management, University of Ss. Cyril and Methodius, Trnava 917 01, Slovakia.

${ }^{2}$ Institute of Industrial Engineering and Management, Faculty of Materials Science and Technology in Trnava, Slovakia University of Technology in Bratislava, Slovakia

${ }^{3}$ Department of Management, Faculty of Business Management, University of Economics in Bratislava, Bratislava, Slovakia

\section{Abstract}

INTRODUCTION: With the arrival of the Fourth Industrial Revolution, the business environment in Slovakia, as well as abroad, determines enormous increase in the number and intensity of changes. In order to remain competitive, it is necessary to respond adequately to this situation. The key to the survival in such environment is the preparation of businesses, and especially the available managers to these changes.

OBJECTIVES: In this paper, the authors of the paper focus on identifying the tendencies of applying selected key managerial competencies, such as a strategic approach to human resources development, effective in-formation sharing or management engagement in the creation of the business innovative organizational culture, within the businesses operating in Slovakia over the past five years.

METHODS: Several research statistical methods were used to achieve the aim of the paper. A questionnaire with 90 questions focused on formal human resource management issues was used.

RESULTS: In the overall assessment of the key managerial competencies analysis, such as the strategic approach to human resources development, effective information sharing or engagement in the creation of innovative organizational culture in enterprises operating in Slovakia over the past five years, a positive trend can be observed.

CONCLUSION: In order to remain competitive, it is necessary to respond adequately to changes of situation. The key to the survival in such environment is the preparation of the managers to these changes. Results point to a positive trend and hope that the unflattering situation of managers' preparation to the beginnings of the Fourth Industrial Revolution will improve in the future.

Keywords: managerial competences, human resources, business environment, innovative culture, Industry 4.0

Received on 01 August 2020, accepted on 26 August 2020, published on 28 August 2020

Copyright (C) 2020 Z. Stacho et al., licensed to EAI. This is an open access article distributed under the terms of the Creative Commons Attribution license, which permits unlimited use, distribution and reproduction in any medium so long as the original work is properly cited.

doi: 10.4108/eai.1-7-2020.166009

\section{Introduction}

The focus on innovation, as a means of ensuring a competitive advantage, is characterized by the enormous competition caused by the globalization policy of the
European Union, characterized by the emergence of a single market, which is specified firstly by the free movement of goods and people, the freedom to pro-vide services and the freedom of the capital movement (Synek, Kislinger et al. 2010 Kampf et al. 2017; Hitka and Sirotiaková, 2011, Cagáňová et al. 2015) and secondly by the strong turbulence currently influenced by the adoption 
of new robotics and digitization technologies as accompanying phenomenon of the Fourth Industrial Revolution becomes a common part of managerial work (Ližbetinová et al. 2016; Hockicko et al., 2015). The competitiveness of the business depends to a large extent on the business's internal environment's ability to identify and respond flexibly to changes in external conditions.

However, the competitiveness of enterprises is primarily influenced by the environment, which is created by the economic policy of individual EU countries. In this area, Slovakia is relatively lagging behind. As reported by the Business Alliance of Slovakia (PAS, 2017) from the Global Competitiveness Report 2017-2018 published by the World Economic Forum (WEF), there is a positive trend. This year, Slovakia has shifted significantly in the competitiveness rankings to 59th place (Schwab 2018). In spite of this positive change, Slovakia remains among the one of the worst-rated countries in the EU. As the most critical areas of the Slovak business environment are the quality of public institutions and the support of talented people.

In order to promote the competitiveness and innovativeness of businesses, the Government of the Slovak Republic proposed in 2015 a tax allowance of $25 \%$ on expenses used on research and development. However, in 2015, businesses ap-plied only for the 9.2 million Euro tax remission, in 2016 it was two million Euro less. For this reason, the Ministry of Finance has also submitted a new proposal, which was approved by the Government in midAugust 2017. According to the new proposal since 1.1.2018, businesses can take all research costs from their tax (Ragáčová, 2017).

\section{Literature review}

\subsection{Strategic approach to human resource development}

The strategic approach of managers on the development of available human re-sources becomes one of the key competencies at the time of the beginning of the Fourth Industrial Revolution, characterized by the need for qualified employees. In order to keep the business competitive, managers have to provide the enter-prise the most talented employees who are not only qualified but also have a high potential for future development. Many studies already report positive results from such process, reflected in the performance indicators of the organization. For example, Joniaková reports the benefits in the area of financial ratios, such as lowering staff turnover costs, lowering costs for obtaining and selecting employees as well as the rise of enterprise activities efficiency. Among those enter-prise activities, increasing the efficiency of the in-house processes, minimizing losses associated with the failure of securing employees in the key positions, delivering results through higher performance and increasing productivity can be classified. (Joniaková
2016). However, the problem is that there is a limited number of talented individuals in the overall population, and therefore enterprises and their managers should do their best to find, acquire, develop and maintain such individuals using all available means.

The most effective way of securing the most talented employees seems to be a strategically thought-out sophisticated system of employee management and development. Lifelong learning is thus becoming an essential part of the lives of both employees and managers (Stachová et al 2019; Tokarčíková, Kucharčíková 2015, Pauliková, et al. 2016). Human capital is considered to be the only source of the business that can be constantly developed (Kucharčíková et al 2018; Vnoučková 2013, Bartáková et al 2017; Cagáňová et al 2017; Grladinović et al. 2007; Križo et al 2018 ) and can be identified in the long term consideration as a key source to make the business more competitive. (Chidambaram 2014, Kruss et all 2015, McDonell et all 2014). Employees who are educated and to whom the organization pay attention to their development are usually highly involved in the work for the enterprise, in reaching goals, are proactive and constantly willing to learn (Li et all 2009, Vnoučková 2013, Arvanitis et all 2015). For this rea-son, one of the key tasks of managers is to identify employees' potential and cre-ate space for their development, which is essential not only for the progress of the organization but also for the employees satisfaction (Rothwell 2010, Vnoučková 2013), who often, by the opportunities for their development, decide whether or not to stay in the organization (Nilson, Elstrom 2012). The departure of talented employees can have a particularly negative impact on the further operation and competitiveness of the enterprise (Urbancová). When an employee with the key knowledge, skills and capabilities necessary for the business leaves the enterprise, the enterprise loses part of its intellectual capital. For this reason, if the enterprise wants to keep these employees, they must be able to negotiate and cooperate with them. Naturally, it is necessary to keep certain limits. It is crucial that the company encourages talents to contribute as much as possible to the objectives of the business and, in accordance with their performance, rewards them accordingly (Branham 2004).

Hroník follows up on the above facts and pushes the idea of strategic insight into employee development even further. He explains, that enterprise's aim should be to maintain as many potential employees willing to learn and develop as possible. For reaching this goal, it is essential to keep two rules. First, initiate the enterprise talent management system, which is usually dedicated to employees responsible for the key business competencies and their successors. Second, the enterprise has to establish education and career management program for all employees, who are expected to remain in the business for more than 5 years. By 3 years time, this education and career management program will positively affect and motivate up to $70 \%$ of employees of the enterprise (Hroník, 2007). 
Efficient employee education and development system responds to constant changes in the environment and leads to increased business performance (Fajčíková et al 2018; Lašáková et al 2017; Lukáč et al 2018; Nedeliaková et al 2017). It is important that education is well organized, systematic and it has to be continuous, within a repeating cycle (Identification -> Planning -> Implementation -> Monitoring). Unfortunately, several surveys show that current education systems within the enterprise do not sufficiently develop the potential of employees. For the reason that the employers do not provide sufficient motivation and incentives, employees often educate themselves and develop their skills on their own. (Schlechter 2014, Hoole, Hotz, 2016, Tansley 2016).

\subsection{Effective information sharing}

Franková characterizes open communication as an unlimited flow of information that allows the combination of partial information. It is oriented in all directions and determined by frequent and intensive contact among individual organizational units (Franková 2011). An effective communication flow is important especially with the task that requires participation of multiple workers, i. e. when cooperation is necessary (Arnfalk et al. 2016; Potkány et al 2016). Effective communication flow is also used when the information flow has to be accelerated, a better understanding of the information needs to be achieved as well as for easier coordination of joint efforts. The more independent work of the departments within the enterprise is, the more important the effective information sharing becomes.

On the one hand, the manager should increase the efficiency of the information flow through the formal communication channels of the company's in-formation system and on the other hand he should also create conditions for effective formal and informal communication in a creative atmosphere. Informal communication is in many cases quicker and more effective than formal communication, while at the same time it fulfills people's need to communicate. The manager should be able to use these advantages of informal communication and seek ways to ensure that the formal information flowing through this channel is accurate (Saniuk 2013). However, informal communication within an organization should be at least partially monitored and managed, as it is often the cause of misunderstandings and rumors that can harm the organization.

The main task of management in the area of effective information sharing is thus to ensure efficient share of information. The phrase "information sharing" expresses a situation where several users have access to single source of information and use it in cooperation (O'Neill et al. 2015). Effective information sharing is used mainly in team-based project solving. The greater the team is, the greater demands on communication efficiency among its members are required. For this purpose, new technologies that have developed significantly with the beginning of the Fourth Industrial Revolution, such as "groupware" (group soft-ware) or intranet, Internet, e-mail (Chory et al. 2016; Droppa et al 2018; Mura 2017), as well as social networking technology. (Kasemsap, 2015; Rózsa et al 2018).

Effective communication in an enterprise is determined by several attributes. First, atmosphere that is created in the enterprise, can be characterized by the fact that subordinates openly comment their suggestions, proposals or requests to the supervisor (Drucker 2008). Thus, the necessary attribute of effective open communication in the enterprise is the existence of trust between the communicating parties (Porvazník 2007). This means that the level of open communication in an enterprise is highly dependent on the organization culture setting.

\subsection{Innovative organizational culture}

Business culture is influenced not only by the managers' managerial activities, but also by their daily behavior. As stated by Lukášová (2010), people in the enterprise are extremely sensitive to what is happening around them. Therefore, the managers themselves, not only the human resources managers, carry both positive and negative behavior patterns to the enterprise employees. The behavior patterns, such as what managers do and do not pay attention to, their behavior in critical situations, emotional responses in situations of norm violations, significantly affect collective learning. Therefore, if managers want to influence the culture of the enterprise in a required way, they need to be aware of these factors. Lukášová (2010) talks about the so-called "culture conscious" business management, which assumes the knowledge of the impact of culture on business performance, the ability to understand the business cultural dynamics and the usage of tools and steps to influence the business cultural dynamics. The management of the enterprise has to promote the desired culture through its management decisions, while acting in accordance with this culture itself (Joniaková, Blštáková 2015).

The environment in which employees work is one of the biggest motivators and not only to performance but also to creativity. In effort to use the potential of human capital in the context of the beginning of the Fourth Industrial Revolution and its associated changes, the primary key role of management is to create an organization culture that encourages creative employee behavior. Thus, in an effort to keep a business competitive, managers need to draw attention to the creation of an organizational culture in which employees have adequate conditions to exploit their own potential for the benefit of the business.

Various empirical researches point out several important factors that positively influence people's creative behavior. First, the best way to maximize employee innovation potential is to allow them to do things they enjoy. That is why, especially in an environment where creativity is needed, management should encourage the employees to 
address the issues that interest them most (Collins, Amabile 2008, Carvaja, et al 2015). Second important factor is creation of a working environment with open communication and efficient information sharing (Franková 2011). This statement is also confirmed by Willems who defines that innovation is stimulated by following rules: open communication, decentralization and trust between different hierarchical levels. The listed rules enable employees on different hierarchical levels communicate freely their ideas and share knowledge within the organization structure. (Willems 2007). Khazanchi (2006) places in-formation, targeted motivation and highly participatory culture among the characteristics of an innovative enterprise. Last but not least, an important role in motivating employees is fulfilled by the application of tools confirming employee's competency, such as reward in the form of freedom in action, time and other resources, praise or positive feedback. (Collins and Amabile 2008) If the enterprise management succeeds in creating such a pro-innovative environment, it is able to take innovative decisions very quickly, which is considered as a significant factor of competitiveness in today's turbulent environment. Priority roles for managers in this context include strengthening trust in management, setting up a stimulus system with a positive impact on innovation activities, creating an environment equivalent for everyone with new improvement proposal and, in particular, support of the innovation implementation.

\section{Materials and Methods}

Several research statistical methods were used to achieve the aim of the pa-per. For the purposes of this paper, data obtained from surveys conducted within years 2014-2018 were used. The survey respondents were the head representatives of enterprises operating in Slovakia. As a tool for exploring the current state of implementation of selected key managerial competencies, a questionnaire with 90 questions focused on formal human resource management issues was used. However, for the purposes of this paper, the authors of the paper processed only answers to questions on the application of selected key managerial competencies in the context of the upcoming industrial revolution. A number of managers ad-dressed in person oscillated approximately 570 each year with a return rate on correctly completed questionnaires ranging from $60 \%$ to $65 \%$.

The research sample consisted of managers working in enterprises within Slovakia, while the authors set two stratification criteria to determine a sufficient research sample. The first criterion was the region of the enterprise operation according to the NUTS system. Slovakia, specifically, was divided by the NUTS 2 category, while the structural composition of the research sample was based on data from the Statistical Office of the Slovak Republic (ک̌Ú SR).

The second stratification criterion was number of employees in the investigated enterprises. The bottom limit was set to 50 employees. Even though micro and small enterprises were excluded from the research sample, the research focused on enterprises in which the skills of the managers were genuinely reflected.

Based on data from the ŠÚ SR monitored during the set period can be concluded that the number of enterprises with 50 or more employees in individual regions oscillated around the same values. The specific regional structure of enter-prises over 50 employees in the years under review is shown in the Table 1 be-low.

Table 1. Regional structure of the enterprises over 50 employees

\begin{tabular}{lllll}
\hline $\begin{array}{l}\text { Region - } \\
\text { NUTS II. }\end{array}$ & $\begin{array}{c}\text { Bratislava } \\
\text { region }\end{array}$ & $\begin{array}{c}\text { Western } \\
\text { Slovakia }\end{array}$ & $\begin{array}{c}\text { Central } \\
\text { Slovakia }\end{array}$ & $\begin{array}{c}\text { Eastern } \\
\text { Slovakia }\end{array}$ \\
\hline $\begin{array}{l}\text { Number of } \\
\text { enterprises }\end{array}$ & 1,098 & 904 & 644 & 612 \\
$\begin{array}{l}2014 \\
\text { Number of } \\
\text { enterprises }\end{array}$ & 1,105 & 916 & 651 & 613 \\
$\begin{array}{l}2015 \\
\text { Number of } \\
\text { enterprises }\end{array}$ & 1,114 & 923 & 649 & 621 \\
$\begin{array}{l}2016 \\
\text { Number of } \\
\text { enterprises }\end{array}$ & 1,123 & 926 & 654 & 623 \\
$\begin{array}{l}2017 \\
\text { Number of } \\
\text { enterprises } \\
2018\end{array}$ & 1,125 & 930 & 659 & 626 \\
\hline \multicolumn{5}{c}{ Source: own elaboration based on Š́́ SR }
\end{tabular}

The size of optimal research sample from the basic set of enterprises was determined by the authors of the paper at $95 \%$ confidence level and confidence interval $(\mathrm{H}=+/$ $0.10)$. On the basis of the above criteria, a sufficient, respectively, relevant research sample for individual regions of Slovakia in the analyzed years was set, which can be seen in the Table 2 .

Table 2. Determination of research sample for individual regions of Slovakia

\begin{tabular}{lcccc}
\hline $\begin{array}{l}\text { Region - } \\
\text { NUTS II. }\end{array}$ & $\begin{array}{c}\text { Bratislava } \\
\text { Region }\end{array}$ & $\begin{array}{c}\text { West } \\
\text { Slovakia }\end{array}$ & $\begin{array}{c}\text { Central } \\
\text { Slovakia }\end{array}$ & $\begin{array}{c}\text { East } \\
\text { Slovakia }\end{array}$ \\
\hline $\begin{array}{l}\text { Size of } \\
\text { research } \\
\text { sample }\end{array}$ & 88 & 87 & 84 & 83 \\
\hline
\end{tabular}

Source: own elaboration

The authors statistically processed and assessed the observed values through the analysis of chain indexes (changes in values are always tracked from the previous year). 


\section{Results}

In the context of the stated aim, the authors identified within the survey the strategic orientation of managers on employee education and development, activities in the area of information sharing support and influence on the creation of innovative organizational culture.

\subsection{Strategic approach to human resource development}

Adapting to change in a competitive environment involves both employees and employers in coping with new challenges, acquiring new knowledge and skills and taking on new roles and responsibilities. A key role is therefore played in particular by the field of education and employee development, which is responsible for ensuring that employees are able and ready to meet these challenges. Based on the above, the authors of the paper have asked in the questionnaire whether enterprises focus on a complex and systematic approach to employee education and development.

Table 3. Chain Index of Changes - Strategic Approach to Human Resources Development

\begin{tabular}{|c|c|c|c|c|c|c|c|c|c|}
\hline \multirow{2}{*}{$\begin{array}{l}\text { Strategic } \\
\text { approach to } \\
\text { human } \\
\text { resource } \\
\text { development }\end{array}$} & \multicolumn{9}{|c|}{ Share of managers } \\
\hline & $\underset{\sim}{\stackrel{\nabla}{\sim}}$ & $\frac{\frac{J}{n}}{\frac{\pi}{0}}$ & $\stackrel{n}{\stackrel{\sim}{े}}$ & $\frac{n}{0}$ & $\stackrel{0}{\circ}$ & $\underset{\sigma}{\stackrel{0}{ }}$ & $\overline{\bar{c}}$ & $\frac{\sqrt{\sigma}}{\sigma}$ & $\frac{\infty}{\stackrel{\sim}{\sim}}$ \\
\hline $\begin{array}{l}\text { Managers } \\
\text { have } \\
\text { developed } \\
\text { an employee } \\
\text { development } \\
\text { strategy } \\
\end{array}$ & 5 & సे & 8 & 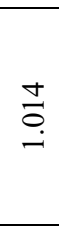 & $\therefore$ & $\underset{\mathrm{f}}{\mathrm{O}}$ & $m$ & $\stackrel{m}{0}$ & $\stackrel{t}{\sim}$ \\
\hline \begin{tabular}{|l|} 
Managers \\
support the \\
education \\
and \\
development \\
of all \\
employees \\
\end{tabular} & q & $\stackrel{\widetilde{o}}{\text {. }}$ & 寸 & 命 & $\mathscr{f}$ & $\stackrel{g}{m}$ & $\stackrel{\infty}{\infty}$ & $\stackrel{\circ}{\stackrel{\circ}{\circ}}$ & $\tilde{\sigma}$ \\
\hline $\begin{array}{l}\text { Businesses } \\
\text { regularly } \\
\text { evaluate the } \\
\text { effectivenes } \\
\text { s of } \\
\text { education } \\
\end{array}$ & 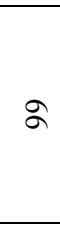 & 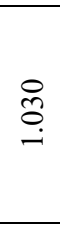 & ฮิ & $\underset{\text { Sे }}{\stackrel{g}{+}}$ & $\hat{\theta}$ & $\stackrel{\text { }}{\text { ¿ }}$ & $\stackrel{\infty}{\varrho}$ & $\stackrel{\hat{o}}{i}$ & $\cong$ \\
\hline$\Sigma$ & ڤे & $\underset{\text { O̦ }}{\text { O̦ }}$ & $\frac{n}{\sim}$ & $\tilde{\sigma}_{-}$ & సి & $\begin{array}{l}\stackrel{\circ}{\circ} \\
\stackrel{-}{-}\end{array}$ & ते & $\stackrel{\hat{\sigma}}{.}$ & $\stackrel{\infty}{\sim}$ \\
\hline
\end{tabular}

Explanatory notes: $\mathrm{ci}$ - chain index - values changed since the previous year
The comparison of the results of individual years shows a slight increase in the sum of the observed attributes in the analyzed period, despite the year-on-year decline in one of the attributes between years 2015 and 2016.

\subsection{Effective information sharing}

One of the basic assumptions of an innovative enterprise is managers' ability to gain interest and enthusiasm for changes in their subordinates. In this paper, the authors of the paper have examined whether managers in selected enterprises create sufficient space for employees' participation in the innovation process. The paper focuses on the issue from the perspective of purposeful guidance and innovative behavior of managers in accordance with the organizational strategy, both in the form of open communication, as well as in the form of correct knowledge sharing. Table 4. Chain Index of Changes - Effective
Information Sharing

\begin{tabular}{|c|c|c|c|c|c|c|c|c|c|}
\hline \multirow[b]{2}{*}{$\begin{array}{l}\text { Effective } \\
\text { information } \\
\text { sharing }\end{array}$} & \multicolumn{9}{|c|}{ Share of managers } \\
\hline & $\underset{\stackrel{\sim}{\circ}}{+}$ & $\underset{⿱ 亠 凶}{\Delta}$ & $\stackrel{n}{\stackrel{\sim}{\sim}}$ & $\begin{array}{l}\frac{n}{0} \\
\frac{0}{0}\end{array}$ & $\stackrel{\circ}{\stackrel{\sim}{\sim}}$ & $\underset{\frac{0}{5}}{\stackrel{0}{\sigma}}$ & $\hat{\stackrel{\sim}{े}}$ & $\underset{\substack{\infty \\
\overrightarrow{0}}}{\stackrel{0}{0}}$ & $\stackrel{\infty}{\stackrel{\sim}{\sim}}$ \\
\hline $\begin{array}{l}\text { Managers } \\
\text { support open } \\
\text { communicati } \\
\text { on at all } \\
\text { management } \\
\text { levels }\end{array}$ & $m$ & $\stackrel{\vec{I}}{\Xi}$ & $\hat{n}$ & 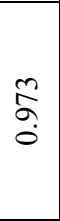 & $\stackrel{i}{n}$ & $\exists$ & \& & $\begin{array}{l}\stackrel{8}{2} \\
\stackrel{2}{-}\end{array}$ & F \\
\hline $\begin{array}{l}\text { Managers } \\
\text { motivate } \\
\text { employees to } \\
\text { share their } \\
\text { knowledge } \\
\text { through } \\
\text { stimulants }\end{array}$ & $=$ & $\begin{array}{l}\infty \\
\stackrel{\infty}{\infty} \\
0 \\
0\end{array}$ & $a$ & 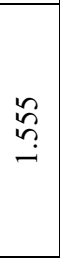 & $\Xi$ & $\begin{array}{l}\stackrel{\infty}{\infty} \\
\stackrel{\sim}{\longrightarrow}\end{array}$ & $\stackrel{\infty}{-}$ & $\underset{\text { సิ }}{\mathbb{Z}}$ & $\tilde{N}$ \\
\hline $\begin{array}{l}\text { Managers } \\
\text { fully share } \\
\text { their } \\
\text { knowledge } \\
\text { and inspire } \\
\text { all } \\
\text { employees }\end{array}$ & $\hat{\sim}$ & $\hat{\tilde{o}}$ & $\stackrel{\infty}{\sim}$ & \begin{tabular}{l}
8 \\
\hdashline \\
0
\end{tabular} & $\stackrel{\infty}{\sim}$ & $\stackrel{\sim}{\tilde{\sigma}}$ & নे & 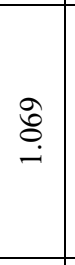 & $\bar{m}$ \\
\hline$\Sigma$ & $F$ & 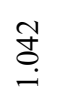 & i & 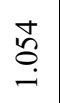 & $\stackrel{\infty}{\sim}$ & $\stackrel{\cong}{\exists}$ & $\hat{\infty}$ & 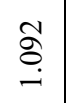 & $\approx$ \\
\hline
\end{tabular}

The comparison of the individual years results shows a slight increase in the sum of the observed attributes in the area of effective knowledge support sharing in each of the monitored years. On the other hand, slightly more 
fluctuating tendencies were recorded after closer examination of the individual attributes.

\subsection{Impact on the creation of an innovative organizational culture}

It is essential for innovative enterprises that they have culture supporting innovative employee behavior established. The survey in this area was aimed at finding out whether an innovation-oriented corporate culture was introduced in the analyzed enterprises, respectively whether the enterprises have an organizational culture strategy developed. The survey also analyzed other factors determining the existence of an innovative corporate culture, such as employee perception of change, which is very favorable in the case of innovative culture.

\section{Table 5. Chain Index of Changes - Impact of managers on the creation of an innovative organizational culture}

\begin{tabular}{|c|c|c|c|c|c|c|c|c|c|}
\hline \multirow{2}{*}{$\begin{array}{l}\text { Impact of } \\
\text { managers on } \\
\text { the creation of } \\
\text { an innovative } \\
\text { organizational } \\
\text { culture }\end{array}$} & \multicolumn{9}{|c|}{ Share of managers } \\
\hline & $\stackrel{\nabla}{\stackrel{\sim}{\sim}}$ & $\frac{\Delta}{\frac{\pi}{\sigma}}$ & $\frac{n}{i}$ & $\frac{n}{\sigma}$ & $\stackrel{0}{\stackrel{0}{\sim}}$ & $\frac{0}{\frac{1}{\pi}}$ & 홍 & $\frac{\sqrt{\infty}}{\frac{\infty}{\sigma}}$ & \\
\hline $\begin{array}{l}\text { The company } \\
\text { has established } \\
\text { innovative } \\
\text { culture }\end{array}$ & $\infty$ & ô & $\infty$ & $\stackrel{\Omega}{\Omega}$ & 2 & $\stackrel{+}{\text { S }}$ & రิ & $\begin{array}{l}\stackrel{\simeq}{\beth} \\
=\end{array}$ & \\
\hline $\begin{array}{l}\text { The primary } \\
\text { focus of } \\
\text { organizational } \\
\text { culture is on } \\
\text { innovation }\end{array}$ & \& & $\vec{a}$ & $\stackrel{\beth}{\beth}$ & $\stackrel{\infty}{0}$ & $\stackrel{\Xi}{\Xi}$ & ڤై & $\stackrel{\infty}{=}$ & के & \\
\hline $\begin{array}{l}\text { Managers } \\
\text { influence } \\
\text { employees to } \\
\text { perceive } \\
\text { change as an } \\
\text { opportunity }\end{array}$ & તี & $\widehat{\widehat{\sigma}}$ & 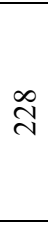 & $\underset{\Xi}{\stackrel{J}{ \pm}}$ & $\underset{\sim}{\sim}$ & ¿̊. & $\stackrel{\infty}{\sim}$ & $\stackrel{m}{0}$ & \\
\hline$\Sigma$ & \& & $\stackrel{\infty}{\infty}$ & $\widehat{\Im}$ & $\underset{-}{\mathbb{O}}$ & f & $\stackrel{2}{0}$ & $\stackrel{\infty}{\sigma}$ & $\underset{-}{\stackrel{J}{0}}$ & $\stackrel{\infty}{\stackrel{\infty}{f}}$ \\
\hline
\end{tabular}

Source: own elaboration

Explanatory notes: ci - chain index - values changed since the previous year

The results of individual years in the examined area are following: the sum of observed attributes values in each of the monitored years increased at the level of 2.5 to 6.8 percentage points. In addition, a more detailed examination of the individual attributes showed positive trends for all attributes throughout the analysis period.
In the overall assessment of the key managerial competencies analysis, such as the strategic approach to human resources development, effective information sharing or engagement in the creation of innovative organizational culture in enterprises operating in Slovakia over the past five years, a positive trend can be observed. Nevertheless, the overall figures are relatively low, and it is questionable whether the improvement rate is sufficient to achieve the level of competitiveness of enterprises operating in Slovakia in comparison with the rapidly developing Europe and world economies.

\section{Discussion}

The requirements for managerial skills differ regarding to the business environment development and the specifics that result from it. The core set of competencies that currently significantly influence the success of a manager's work in the context of the beginnings of the Fourth Industrial Revolution include the capabilities to use and develop the enterprise's innovation potential. Regarding to above mentioned, it is essential to focus on the efficient use of the enterprise's available resources, while human resources play a key role in meeting these goals. As a result, to maintain business competitiveness, managers need to provide the enterprise with the most talented employees who are not only qualified but also have a high potential for future development.

Unfortunately, as Hronik 2007 claims, talent management and career management have so far been considered by managers as something that is intended only for a small group of the most talented employees. This statement is confirmed by a survey by Urbancová 2016, in which only $17 \%$ of respondents confirm the potential existence of talented people at all levels in the enterprise. However, many surveys point to the need to perceive the need for development for all employees who are expected to remain in the organization for more than 5 years. In this case, after only 3 years can be achieved that the career management will affect up to $70 \%$ of employees in the organization (Hroník 2007).

From the above mentioned can be concluded, that within the framework of career management, it is necessary to seek talented people across the whole organization. In order to avoid the perception of talent as an "elite", avoid inequality or prevent internal "disintegration" of the enterprise (Snipes, 2005), talent management needs to be formalized through a strategy that directly specifies both the benefits and the obligations of chosen employees. In this context, the findings of the authors, which point to the overall increase in the managers orientation to a comprehensive and systematic approach to employees' education and development in enterprises operating in Slovakia, can be evaluated positive.

Various empirical researches point to several important factors that positively influence creative behavior of individuals. In an environment where creativity is needed, management should encourage the employees to focus on 
the issues that interest them most (Collins, Amabile 2008, Carvaja, et al 2015). The application of tools confirming employee's competency, such as reward in the form of freedom of action, time and other resources, praise or positive feedback, also play an important role in employees' motivation. (Collins and Amabile 2008)

The overall increase in the attributes of managers' orientation towards the creation of an innovative organizational culture in organizations operating in Slovakia was observed by the authors of the paper towards the first year of the monitored period at 19.5 percentage points. The authors of this paper consider this trend quite positive.

Another important factor supporting the use and development of innovation potential is the creation of an environment with open communication and effective information sharing (Franková 2011). This is also confirmed by Willems who defines that innovation is stimulated by open communication, decentralization and trust between different hierarchical levels, which enable employees on different hierarchical levels communicate freely their ideas and share knowledge within the organization structure. (Willems 2007).

In this context, the authors consider the study results to be very positive, as the overall increase in the attributes of managers orientation to support effective information sharing towards the first year of the monitored period was quite significant with the value of 33.8 percentage points.

\section{Conclusion}

In order to remain competitive, it is necessary to respond adequately to this situation. The key to the survival in such environment is the preparation of the managers to these changes. In the paper, the authors focused on identifying the tendencies of applying selected key managerial competencies as a strategic approach to human resources development, effective information sharing or management engagement in the creation of the business innovative organizational culture, within the businesses operating in Slovakia over the past five years.

In the context of the overall share of examined attributes toward the whole sample, the results of the survey showed relatively negative results. The last analyzed year pointed out, that managers only support the education and development of all employees in $(n=62)$ cases, which represents $18.4 \%$ of the total number of respondents, managers fully share their knowledge and inspire all employees only in $(n=31)$ cases, representing $9.2 \%$ and managers support open communication at all levels of management in $(n=42)$ cases, representing $12.5 \%$.

The field of the organizational culture achieved better results, as the survey showed that it is introduced in $(\mathrm{n}=$ $115)$ enterprises, i. e. $34.1 \%$ of respondents. These results indicate a very poor preparation of managers operating in enterprises in Slovakia to the current business environment.
However, the findings of the authors also point to the overall increase in the orientation of managers in enterprises operating in Slovakia on all monitored attributes. While in the managers orientation on employee education and development was observed overall increase of only $3.7 \%$, in the orientation towards the creation of an innovative organizational culture an overall increase of $19.5 \%$ was recorded. In the area of effective information sharing an overall increase of $33.8 \%$ was observed. These results point to a positive trend and hope that the unflattering situation of managers' preparation to the beginnings of the Fourth Industrial Revolution will improve in the future.

\section{Acknowledgements.}

This research was supported and funded by APVV-17-0656 titled "Transformation of Paradigm in Management of Organizations in the Context of Industry 4.0", 2/0077/19 VEGA project titled "Work competencies in the context of Industry 4.0" and with support of 1/0412/19 VEGA project titled "Systems of Human Resources Management in the 4.0 Industry Era”.

\section{References}

[1] Arnfalk, P.; Pilerot, U.; Schillander, P.; Grönvall, P. 2016. Green IT in practice: virtual meetings in Swedish public agencies, Journal of Cleaner Production 123(1): 101-112. https://doi.org/10.1016/j.jclepro.2015.08.063

[2] Arvanitis S., Lookshin B., Mohnen P. et al. (2015). Inpact of External Knowledge Acquisition Strategies on Innovation: A comparative Study Based on Dutch and Swiss Panel Data. Review of Industrial Organization, 46(4), 359382. DOI: $10.1007 / \mathrm{s} 11151-015-9450-7$

[3] Bartáková, G.P., Gubíniová, K., Brtková, J. 2017. Mapping the development and processes of emerging "green markets" in the context of sustainable marketing management. Smart City 3602016 - 2nd EAI International Summit

[4] Bessant, J. 2003. High Involvement Innovation. John Wiley \& Sons, 2003. 256 s. ISBN 978-0-470-84707-7

[5] Branham, L. 2004. Jak si udržíte nejlepší zaměstnance. Brno: Computer Press, 327 s. ISBN 80-251-0223-7

[6] Cagáňová, D., Bawa, M., Šujanová, J., Saniuk, A. 2015. Innovation in Industrial Enterprises and Intercultural Management. 1. ed. Zielona Góra : University od Zielona Góra,. 126 s. ISBN 978-83-933843-4-1

[7] Caganova, D., Starecek, A., Bednarikova, M., Hornakova, N. 2017. Analysis of factors influencing the motivation of generations $\mathrm{y}$ and $\mathrm{Z}$ to perform in the educational process. ICETA 2017 - 15th IEEE International Conference on Emerging eLearning Technologies and Applications, Proceedings 8102471

[8] Carvaja, S.A., Pérez, M.D., Cabello, R.V. \& Espinosa, C.C. (2015). Identifying key factors affecting culture of innovation: A case study of Chilean medium mining sector Journal of Technology Management and Innovation 10 (1), pp. 132-145

[9] Collins, M. A. \& Amabile, T. M. (2008). Motivation and Creativity In: Handbook of Creativity. Cabridge: Cambridge University press. ISBN 978-0-521-57604-8

[10] Droppa, M., Birknerová, Z., Frankovský, M., Križo, P. 2018. Assessment of bossing in secondary school environment in the Slovak Republic, depending on the 
length of practice of the respondents. TEM Journal 7(2), pp. 35

[11] Drucker, P. F. 2008 Efektivní vedoucí Praha: Management Press 205 s. ISBN 978-80-7261-189-8

[12] Fajčíková, A., Urbancová, H., Kučírková, L. 2018. Decisive factors of talent management implementation in Czech organisations. Journal on Efficiency and Responsibility in Education and Science 11(1), pp. 9-15

[13] Franková, E. (2011). Kreativita a inovace v organizaci Praha: Grada Publishing 2011. 254 s. ISBN 978-80-2473317-3

[14] Grladinović, T., Oblak, L. \& Hitka, M. (2007). Production management information system in wood processing and furniture manufacture. Drvna Industrija. Vol. 58, Issue 3, 2007, pp. 141-146.

[15] Hitka, M., Sirotiakovà, M. The impact of economic crisis on the change in motivation of furniture company employees case study. Drewno, 2011, Vol. 54, No. 185, pp. 119-126.

[16] Hockicko, P., Kristak, L., Nemec, M. Development of students' conceptual thinking by means of video analysis and interactive simulations at technical universities. European Journal of Engineering Education, 2015, Vol. 40, No. 2, pp. 145-166.

[17] Hoole, C., Hotz, G. (2016). The Impact of a Total Reward System of Work Engagement, Journal of Industrial Psychology, 42(1), 1-14.

[18] Hroník, F. (2007). Rozvoj a vzdelávaní pracovníků. Praha: Grada Publishing.

[19] Chidambaram, R. (2014). To become a knowledge Economy. Curent Science, 106(7), 936-941.

[20] Chory, R.M., Vela, L.E., Avtgis, T.A. Organizational Surveillance of Computer-Mediated Workplace Communication: Employee Privacy Concerns and Responses Employee Responsibilities and Rights Journal vol. 28, no. 1, 2016, pp. 23-43

[21] Jankelova, N., Joniakova, Z., Blstakova, J. \& Nemethova, I. (2017). Readiness of human resource departments of agricultural enterprises for implementation of the new roles of human resource professionals In: AGRICULTURAL ECONOMICS-ZEMEDELSKA EKONOMIKA, Vol.63, Iss.10, pp. 461-470, ISSN: 0139-570X; eISSN: 1805-9295

[22] Joniaková Z., Gálik, R. Blštáková, J., Tarišková, N. 2016. Riadenie l'udských zdrojov Bratislava: Wolters Kluwer. 456 s. ISBN 978-80-8168-532-3

[23] Joniaková, Z., Blštáková, J., (2015). Age Management as Contemporary Challenge to Human Resources Management in Slovak Companies. 9th International Scientific Conference on Business Economics and Management (BEM) Location: Tech Univ Zvolen, Izmir, TURKEY Date: APR 30-MAY 02, 2015 pp.202-209

[24] Kampf, R., Lorincová, S., Hitka, M., Stopka, O. (2017). Generational Difference in the Perception of Corporate Culture in European Transport Enterprise. Sustainability, 9(9).

[25] Kasemsap, K. 2015. The role of social networking in global business environments, Social Media and Networking: Concepts, Methodologies, Tools, and Applications 3-4(1): $1635-1652$

[26] Khazanchi, S., Lewis, W. M. \& Boyer, K. K. (2006). Innovation-Supportive Culture: The Impact of Organizational Values on Process Innovation. Journal of Operations Management, 2007, 25(4):871-884, 2006.

[27] Kremský, P., Kušnirik, A. 2017. Eurofondy v regiónoch aké ovocie priniesli bruselské peniaze? Podnikatel'ská aliancia Slovenska. (PAS) 44 p. alianciapas.sk/wpcontent/uploads/2017/11/eurofondy-analyza.pdf
[28] Križo, P., Chocholáková, A., Sirotiaková, M. 2018. Using knowledge management in scientific work - time analysis. Communications in Computer and Information Science 877 , pp. $15-25$

[29] Kruss, G., McGrath, S., Petersen, I. H. Gastrow, M. (2015). Higher Education and Economic Development: The Importance of Building Technological Capabilities. International Journal of Educational Development, 43, 2231 DOI: 10.1016/j.ijedudev.2015.04.011

[30] Kucharčíková, A., Mičiak, M., Hitka, M. 2018.Evaluating the effectiveness of investment in human capital in ebusiness enterprise in the context of sustainability. Sustainability (Switzerland). 10(9),3211

[31] Lašáková, A., Remišová, A., Kirchmayer, Z. 2017. Are managers in Slovakia ethical leaders? key findings on the level of ethical leadership in the Slovak business environment Periodica Polytechnica Social and Management Sciences 25(2), pp. 87-96

[32] Li J., Brake G., Champion A., Fuller T., Gabel, S. Hatcherbusch L. (2009). Workplace Learning: The Roles of Knowledge Acccessibility and Management. Journal of Workplace Learning, 21(4), 347-364.

[33] Ližbetinová, L., Lorincová, S. \& Caha, Z. (2016). The application of the organizational culture assessment instrument (OCAI) to logistics enterprises. Nase More. Vol. 63, Issue 3, 2016, pp. 170-176.

[34] Lukáč, M., Mihálik, J. 2018. Data envelopment analysis - A key to the museums' 'Secret Chamber' of marketing? Communication Today 9(2), pp. 106-116

[35] Lukášová, R. (2010). Organisational Culture and its Change. Praha: Grada Publicshing

[36] McDonell, A., Lavelle, J., Gunnigle, P. (2014). Human Resource Management in Multinational Enterprises: Evidence from a Late Industrializing Economy. Management International Review, 54(3), 361-380.

[37] Mura, L., Havierniková, K., Machová, R. 2017. Empirical results of entrepreneurs' network: Case study of Slovakia. Serbian Journal of Management 12(1), pp. 121-131

[38] Nedeliaková, E., Panák, M., Šipuš, D. 2017. Innovative trends in process-oriented quality management within railway transport. Periodica Polytechnica Transportation Engineering 45(2), pp. 84-89

[39] Nilson, S., Elström, P. E. (2012). Employability and Talent Management: Challenges for HRD Practices. European Journal of Training and Development, 36(1), 26-45.

[40] O’Neill, T. A.; Hancock, S. E.; Zivkov, K.; Larson, N. L.; Law, S. J. 2015. Team decision making in virtual and faceto-face environments, Group Decision and Negotiation 23(1): 1-26.

[41] Pauliková, A., Nováková, R., Šujanová, J. 2016. Increasing of quality management by means of coordination of dangerous substance storage for environmental protection. International Multidisciplinary Scientific GeoConference Surveying Geology and Mining Ecology Management, SGEM 2, pp. 463-470

[42] Philipps, A. (2010). Drawing Breath: Creative elements and their exile from higher education. Arts and Humanities in Higher Education, 9. p. 42-53

[43] Pilková, A., Papula, J., Volná, J. \& Holienka, M. (2013). The influence of intellectual capital on firm performance among Slovak SMEs. In International Conference on Intellectual Capital, Knowledge Management and Organisational Learning. ACPI. pp. 329-338.

[44] Porvazník J. 2018. Celostný manažment. Bratislava: IRIS, 2018. 240 s. ISBN 978-80-8200-023-1 
[45] Potkány, M., Stasiak-Betlejewska, R., Kováč, R., Gejdoš, M. 2016. Outsourcing in contidions of SMEs - The potential for cost savings | [Outsourcing w warunkach Małych I Średnich przedsiębiorstw - Potencjał w zakresie oszczędności kosztowej]. Polish Journal of Management Studies 13(1), pp. 145-156

[46] Ragáčová, K. 2017. Daňová úl'ava na výskum sa kontroluje l'ahšie ako eurofondy In: Trend.sk News and Media Holding, (online). (Cit. 2018-3-12). Available at: https://www.etrend.sk/trend-archiv/rok-2017/cislo-

35/danova-ulava-na-vyskum-sa-kontroluje-lahsie-akoeurofondy.html

[47] Rothwell, W. J., Williams, T. (2010). Effective Succession Planning: Ensuring Leadership Continuity and Building Talent from within. New York: Amacom.

[48] Rózsa, Z., Zbranková, H., Rahman, A. 2018. Gender differences of managing banks' credit portfolio. Polish Journal of Management Studies 18(2), pp. 222-283

[49] Saniuk, A., Cagánová, D., Čambál, M. 2013. Performance management in metalworking processes as a source of sustainable development. METAL 2013 - 22nd International Conference on Metallurgy and Materials, Conference Proceedings pp. 2017-2022

[50] Schlechter, A., Hung, A., Bussin, M. (2014). Undestanding Talent Atraction: The Influence of Financial Rewards Elements on Perceived Job Attractiveness: Original Research. SA Journal of Human Resource Management, 12(1) $1-13$.

[51] Schwab, K. 2018 The Global Competitiveness Report 2018 WEF ISBN-13: 978-92-95044-76-0, www3.weforum.org/docs/GCR2018/05FullReport/TheGlo balCompetitivenessReport2018.pdf

[52] Stachová, K.; Papula, J.; Stacho, Z.; Kohnová, L. (2019). External Partnerships in Employee Education and Development as the Key to Facing Industry 4.0 Challenges. Sustainability 11(2) p. 345

[53] Synek, M. \& Kislingerová, E. et al., (2010). Podniková ekonomika Praha: C.H. Beck, 498 s. ISBN 978-80-7400336-3

[54] Tansley, C., Hafermalz, E., Dery K. (2016). Talent Development Gamification in Talent Selection Assessment Centres, European Journal of Training and Development, 40(7), 490-512. https://doi.org/10.1108/EJTD-03-20160017

[55] Tokarčíková, E. \& Kucharčíková, A. (2015). Diffusion of innovation: The case of the Slovak mobile communication market. International Journal of Innovation and Learning. 17 (3), pp. 359-370.

[56] Vnoučková, L. (2013). Employee Learning and Development in Organizations. Journal of Efficiency and Responsibility in Education and Science, 6(3), 179-189. DOI: 10.7160/eriesj.2013.060305

[57] Watson, E. (2007). Who or What Creates? A Conceptual Framework for Social Creativity. Human resource Development Review. vol. 6 no. 1, ISSN 1534-4843. s. 419441

[58] Willems, M. J. T. (2007). The Influence on Social Capital and Cultural Dimensions of Innovation, Master's Thesis, Universiteit Maastricht. 2007. [online]. [cit. 23.1.2016] Dostupné na internete: http://arno.unimaas.nl/show.cgi?fid=11419

[59] Zelina, M. \& Zelinová, M. (1990). Rozvoj tvorivosti detí a mládeže. Bratislava: SPN ISBN 80-08-00442-8. 